\title{
Activation and Onset Time of the Gluteus Maximus Muscle during Three Different Prone Table Hip Extension Exercises
}

In-Cheol Jeon

Department of Physical Therapy, College of Life and Health Science, Hoseo University, Research Institute for Basic Sciences, Hoseo University, Asan, Republic of Korea

Purpose: The purpose of this study was to compare the electromyographic activity and onset time of the gluteus maximus (GM) and hamstring (HAM), lumbopelvic kinematics during three different prone table hip extension exercises in healthy individuals.

Methods: Twenty subjects were participated. Electromyography device was used to measure the muscle activities and onset time of the GM and HAM muscles. An electromagnetic tracking motion device was used to measure lumbopelvic compensations. The subjects were asked to perform three different prone table hip extension [Prone table hip extension with the abdominal drawing-in maneuver on a chair (PTHEA), PTHEA with the ipsilateral knee flexion (PTHEAF), PTHEAF with hip 30 abduction (PTHEAFA)]. One-way repeated measures analysis of the variance and a Bonferroni post hoc test were used.

Results: The electromyographic activity and onset time were significantly different among three conditions (PTHEA vs. PTHEAF vs. PTHEAFA) $(p<0.01)$. The GM muscle activity and onset time were significantly greater and reduced during the PTHEAFA compared to PTHEA and PTHEAF $(p<0.01)$. However, The HAM muscle activity and onset time were significantly smaller and delayed during the PTHEAFA compared to PTHEA and PTHEAF $(p<0.01)$.

Conclusions: PTHEAFA exercise can be recommended to facilitate the muscle activity and efficient muscle firing time of GM without HAM dominance.

Keywords: Gluteus maximus, Muscle activity, Onset time, Prone table hip extension

서 론

큰볼기근(gluteus maximus, $\mathrm{GM}$ )은 엉덩관절 주변의 근육에서 가장 크고, 표면에 위치한 근육이다.' 볼기근육의 그룹은 큰볼기근, 중간볼 기근 그리고 작은볼기근 3 가지 근육으로 구성되어 있다. 큰볼기근은 넓고 두꺼운, 사각형 모양의 근육이며, 이 근육의 근섬유 방향은 비 스듬히 아래쪽과 바깥쪽으로 향해있다. 또한 이 근육은 주로 엉덩관 절에서 강력한 폄근과 바깥쪽 돌림근역할을 한다. 큰볼기근의 근섬 유 방향은 엉치뼈로부터 넙다리뼈 큰돌기(femur greater trochanter)를 향하기 때문에, 아래쪽 그리고 바깥쪽으로 대략 $30^{\circ}$ 의 각도를 형성하 고 있다. 또한, 엉치엉덩관절을 수직으로 가로지르기 때문에, 수축 시 엉치엉덩관절면의 수직방향으로 압박하면서 안정성을 증가시킨다. ${ }^{4.5}$ 이러한 요소는 보행 또는 뛰기와 같은 기능적인 활동 동안에 엉치엉 덩관절을 통해서 하지에서 골반으로 힘 전달(force transmission) 메커
니즘에 기여한다. ${ }^{6}$

큰볼기근 근활성도의 부적절한 수축 타이밍은 허리통증 (low back pain, LBP)을 발생시키는 원인이 될 수 있다.4.5 그러므로, 허리 통증이 있는 환자에서 뒤넙다리근(hamstring) 근 수축 개시시간(onset time) 이 큰볼기근의 개시시간보다 더 빠른 것으로 알려졌다. ${ }^{78}$ 또한 큰볼기 근의 약화는 뒤넙다리근과 같은 협동근의 보상작용을 야기시킨다.4,5 따라서, 선택적이고, 효율적인 큰볼기근 강화 운동은 허리통증 및 하 지 손상에 대한 재활을 위해 임상적으로 필수적이다. 이에 따라, 많은 선행 연구에서 큰볼기근의 지연 시간을 줄이기 위한 다양한 방법을 연구했다.910 그 중에 엎드려 엉덩관절 폄(prone hip extension, PHE)운 동 동안에 압력 바이오피드백 도구(pressure biofeedback unit, PBU)를 이용하여 복부 당기기(abdominal drawing in maneuver)를 수행할 경 우, 뒤넙다리근에 비해서 큰볼기근의 지연을 감소시킬 수 있었다.910 또한 PHE 동안에 큰볼기근의 활성도가 떨어질 때, 근 수축 지연이 일 
어났지만, 신호를 줌으로써 뒤넙다리근과 큰볼기근의 근 수축 개시 시간을 거의 동시에 발생시킬 수 있었다."

Wilson 등'2은 가장 효과적인 큰볼기근 강화운동으로 풀스쿼트 (full squat)운동을 추천했다. Distefano 등 ${ }^{13}$ 은 한발스쿼트(single-limb squat)가 큰볼기근의 최대 근활성도를 유도한다고 보고했다. 하지만, 이러한 운동의 유형은 일반적으로 건강한 사람들이 체육관에서 수 행할 수 있는 고강도 운동들이다. 이러한 운동은 하지 관절이나 안정 성 문제가 있는 환자 또는 근력운동의 강도를 점진적으로 향상시킬 필요가 있는 대상자에게는 적용하기 어렵기 때문에, PHE 운동은 큰 볼기근을 강화하기 위한 재활에 일반적으로 많이 사용되어 왔다.12-14 PHE 운동을 수행하면서 무릎굽힘 $90^{\circ}$ 를 병행하면 뒤넙다리근의 능 동적 불충분(active insufficiency)을 일으키기 때문에, 큰볼기근의 선 택적인 강화 운동이 가능하다. 45 이 자세는 임상적으로 PHE 운동시 큰볼기근의 선택적 강화를 위해 많이 사용하는 운동자세이다.

Comerford와 Mottram ${ }^{15}$ 는 허리뼈와 골반을 조절하기 위해, 큰볼기 근과 복부 근육을 활성화시키는 테이블에 엎드려 엉덩관절 폄 (prone hip extension, PTHE) 운동을 제안하였다. 특히 이 운동은 몸통을 테 이블 위에서 지지된 채, 양발은 지면에 내려놓고, 허리뼈는 중립자세 에 두고 수행된다. 그러나 허리골반부위에서 안정화되지 않을 때, PTHE 운동뿐만 아니라 PHE 운동들은 허리뼈에서 과도한 폄과 돌림 이 보상작용으로 나타날 수 있다. 또한 골반에서는 앞기울임(anterior tilting)과 돌림(rotation)이 발생될 수 있다.5-17 다양한 PHE 운동을 수 행하면서, 압력 바이오피드백 도구를 이용하여 복부 당기기를 수행 할 경우, 허리골반 부위의 보상작용은 최소화된다고 보고하였다.10,16 PTHE 운동으로 수행할 경우, 몸통을 테이블 위에서 지지하고, 양발 을 지면에 고정한 채, 엉덩관절 폄을 수행하기 때문에 골반이 비교적 중립자세로부터 뒤기울임 된 상태에서 진행된다. 15,17 이 자세로 인해 서 PTHE 운동을 수행하는 것이 운동자각도(rating of perceived exertion, RPE)에서 매우 힘든 단계(17.2 \pm 2.3$)$ 에 해당한다고 설명하였다. ${ }^{17}$ PTHE를 수행하면서 이러한 단점을 보완하고, 좀 더 쉬운 자세에서 큰볼기근 강화운동을 효과적으로 수행할 수 있도록, 보완된 PTHE 에 대해서 연구하고자 한다. 임상적인 관점에서 볼 때, 일반적인 PTHE 운동을 수행하는 것은 엉덩관절 폄을 하기 위해 PHE보다 횔 씬 많은 노력이 필요하므로, ${ }^{17}$ 본 연구에서는 PTHE 운동을 보다 쉽게 수행할 수 있고 보상작용을 최소화한 채 큰볼기근의 근활성도를 효 과적으로 향상시키기 위해서, 반대쪽 지지하는 다리에 의자로 서포 트를 할 예정이다. 이 방법은 일반적으로 Comerford와 Mottram ${ }^{15}$ 가 제시한 PTHE 운동과 비슷하지만, 큰볼기근을 효과적으로 운동시키 기 위해 보완된 새로운 운동 방법이라고 할수 있다. 또한 일반적인 방 법인 PHE 운동의 경우 Prone position에서 하지를 지면에 모두 밀착시 킨 채 수행하는 자세인 반면에, 이 연구에서의 차별성은 임상적으로
테이블에 기대서 수행하는, 변형된 형태의 Prone table hip extension 운동들의 비교라고 볼 수 있다. 지금까지의 연구동향을 살펴보면, 건 강한 사람을 대상으로 보완된 세가지 다른 PTHE 운동[Prone table hip extension with the abdominal drawing-in maneuver on a chair. (PTHEA) vs. PTHEA with the ipsilateral knee flexion (PTHEAF) vs. PTHEAF with hip 30 abduction (PTHEAFA)]을 수행했을 때, 큰볼기근, 뒤넙다리근의 근 활성도와 근 수축 개시시간 그리고 보상작용을 비교한 연구는 이뤄 지지 않았다. 따라서 본 연구의 목적은 건강한 대상자가 PTHEA, PTHEAF 그리고 PTHEAFA의 세 가지 다른 PTHE 운동을 수행하는 동안 큰볼기근과 뒤넙다리근의 근활성도와 근 수축 개시시간 그리 고 허리골반부위의 보상작용을 비교하는 것이다. 본 연구의 가설은 PTHEAFA 운동을 수행할 때, PTHEA와 PTHEAF 때 보다 근활성도 에 있어서, 큰볼기근의 유의한 증가와, 뒤넙다리근의 유의한 감소를 보일 것으로 설정하였다.

\section{연구 방법}

\section{1. 연구대상}

총 20 명의 건강한 남성이 연구를 위해 모집되었다. ${ }^{17}$ 실험대상자의 특 성은 다음과 같다. 1) 평균나이(24.1 \pm 4.2 세), 2) 평균체중 $(73.1 \pm 4.3 \mathrm{~kg})$, 3) 평균신장 $(172.1 \pm 6.8 \mathrm{~cm})$ 이다. 선정기준은 1) 엉덩관절 및 무릎관절 에 특별한 질환이 없는 자, 2) 최근 12 개월 이내에 관절 통증이나 질병 이 없던 자를 대상으로 선정하였다. 제외 기준은 다음과 같다. 1) 토마 스 테스트 양성 반응-엉덩허리근 단축이 있는 자, ${ }^{17} 2$ ) 앞십자인대 염 좌, 만성 발목 불안정성 또는 지난 12 개월 안에 하지 부위에 장애를 받은 자, 3) 테스트 중 통증을 호소하는 자, 4) 양측 무릎 및 발목 관절 의 제한된 운동 범위를 갖고 있는 자로 설정하였다. 실험 프로토콜은 모든 실험대상자에게 자세히 설명되었으며 각 실험대상자는 사전 서 면 동의를 제공했다. 이 연구는 기관 검토위원회의 승인(No. 1041849201510-BM-074-01)을 받았다.

\section{2. 실험방법}

1) 측정방법 및 도구

(1) 근활성도 및 근 수축 개시시간

EMG-feedback (TeleMyo 2,400T, Noraxon, USA) 장비를 이용하여 근 활성도와 근 수축 개시시간을 측정하였다. 엉덩관절에 큰볼기근과 뒤넙다리근의 근활성도를 포함한 근 수축 개시시간을 분석하기 위 해 전용 소프트웨어가 포함된 프로그램을 사용하였다. $20-450 \mathrm{~Hz}$ 의 대역통과필터, $60 \mathrm{~Hz}$ 의 여과필터, $1,024 \mathrm{~Hz}$ 의 표본추출률로 설정하였 다. 수집된 모든 근활성도 데이터는 moving window가 $50 \mathrm{~ms}$ 인 the root mean square (RMS)를 사용하여 신호를 처리했다. 전극 배치를 하 
기 전에, 피부 저항을 최소화하기 위해 부착 부위를 면도하고 나서, 알코올 솜을 사용하여 피부를 깨끗하게 했다. 일회용 $\mathrm{Ag} / \mathrm{AgCl}$ 표면 전극을 해당 부위에 적용했다. Rainoldi 등18에 의해 자세히 설명된 대 로 실험대상자의 중간 부분 근육 위에 전극을 부착했다. 두 개의 전 극을 오른쪽 큰볼기근(S2가시돌기과 엉덩뼈 큰돌기 사이 $50 \%$ 지점), 오른쪽 뒤넙다리근(볼기주름과 다리오금 사이 $50 \%$ 지점)에 해당하 는 타겟 근육에 전극을 부착하였다. 큰볼기근 및 뒤넙다리근의 최대 자발적 등척성 수축(MVIC)에 대한 근육 테스트 위치는 Kendall 등 19 의 지침에 따라 진행되었고, \%MVIC는 각 근육 수축을 정규화하기 위해 사용되었다. 각 실험대상자가 타겟바에서 자신의 우세측 다리 를 폄을 유지하는 동안 5 초 동안의 근활성도 신호가 기록되었다. 시 험 시작 및 종료 시 각각의 1 초를 제외하고, 중간 $2-4$ 초의 신호를 분석 했다. ${ }^{7}$

근 수축 개시시간 분석은 동일한 근전도 측정장비를 사용하였고, MyoReaseach Master Edition 1.06 XP software (Noraxon, Scottsdale, AZ, USA) 프로그램을 사용하였다. 근활성도 분석을 통해 얻어진 데이터 를 RMS 처리하였고, 전용프로그램을 통해 근 수축 개시시간을 분석 하였다. 세 가지 다른 PTHE 운동을 시작하기 전, 근전도 신호가 시작 된 시점부터 $100 \mathrm{~ms}$ 기간 동안의 평균값에 대한 표준편차(standard deviation, $\mathrm{SD}$ )를 분석했다. 그 수치를 기준으로 $3 \mathrm{SD}$ 를 $25 \mathrm{~ms}$ 이상으 로 지속되는 첫 지점을 각 근육에 대한 상대적인 근 수축 개시시간으 로 설정하였다. ${ }^{20}$

\section{(2) 운동학적 측정}

Polhemus Liberty ${ }^{\mathrm{TM}}$ (Polhemus Inc., Colchester, VT, USA)를 사용 하여 $120 \mathrm{~Hz}$ 에서 허리골반 보상작용을 조사하였다. 운동 중 앞 기울임 및 돌림의 보상작용을 관찰하였다. 간섭을 피하기 위해 금속 물체는 제거됐다. S2에 전자기 모션센서가 부착되었다. 모 션 아티팩트를 감지하기 위해 센서와 와이어를 동일한 부위에 접착 테이프로 단단히 고정했다. 송신기는 모든 PTHE 운동 중 에 동일한 위치와 방향을 유지했다. 전자기 추적기 시스템은 PTHE의 방향으로 정렬되었으며, $+\mathrm{X}$ 는 anterior superior iliac spine (ASIS)선에 평행하고 $+\mathrm{Y}$ 는 앞-뒤 축을 따라 향하고 $+\mathrm{Z}$ 수 직 (위쪽) 축을 따라 향해 측정되고 계산됐다. $\mathrm{S} 2$ 의 센서를 사용 하여 골반 기울임과 돌림 각도가 측정되었다. 시상면과 가로면 에서, 초기 위치와 최종 위치의 각도차이를 사용하여 운동 중 골반 기울임 및 회전을 측정했다.

\section{3. 실험 절차}

측정자는 블라인드 상태에서 반복 측정 설계를 사용했다. 20 명의 실 험대상자는 Microsoft Excel (Microsoft, Redmond, USA)을 사용하여
무작위 순서로 세 가지 다른 PTHE를 수행했다. 일정한 속도로 운동 을 수행할 수 있도록 메트로놈을 초당 1 박자로 설정했다. 실험대상자 들은 높이 조절이 가능한 테이블에서 엎드린 자세를 취하도록 했다. 엉덩이 폄 각도가 $10^{\circ}$ 타겟바까지 도달할 때까지 수행하였다. 엉덩관 절 폄 $10^{\circ}$ 를 확인하기 위해, 고니오미터를 사용하여 엉덩관절의 각도 를 측정하였다. 모든 운동을 하는 동안 타겟바는 다리오금 중심으로 부터 $5 \mathrm{~cm}$ 위에 위치했다. 엉덩관절 폄이 시작되고부터 엉덩관절 폄 각도가 $10^{\circ}$ 에서 유지될 때까지 근전도 데이터가 총 10 초 동안 수집되 었다. 엉덩관절 폄 유연성을 평가하기 위해, 토마스 검사(Thomas test) 를 사용하여 엉덩허리근을 평가했다. 토마스 검사는 측정테이블 끝 에서 측정하는 쪽의 다리를 내놓은 상태에서 엉덩관절 각도를 측정 하면서 진행된다. 양성반응은 엉덩관절 폄 각도가 제한적이며, 단일 관절의 엉덩굽힘근에 단축이 있다고 확인했다. 압력 바이오피드백 도구는 모든 운동 동안에 복부와 테이블 사이에 배치되었다. 모든 실 험대상자는 압력 바이오피드백 도구에 익숙할 수 있도록 연습을 충 분히 하였고, 모든 연습은 실험진행자에 의해 확인되었다. 각 실험대 상자는 축구 공을 차는데 선호되는 다리로 정의되는 우세적인 다리 를 사용하여 모든 운동을 수행했다. ${ }^{17}$ 초기 위치에서 타겟바까지 폄 동작을 5 초 동안 수행하고, 타겟바 레벨에서 5 초 동안 유지했다. 실험 대상자는 타겟바에 닿을 때까지 우세적인 다리를 들어 올렸다. 타겟 바에 도달한 후 엉덩관절 폄을 5 초 동안 유지하였다. 근육 피로를 최 소화하기 위해 운동 사이에 3 분의 휴식을 취하면서 3 회 연속 반복을 수행했다. ${ }^{17}$

\section{4. 실험자세}

1) Prone table hip extension with the abdominal drawing-in maneuver on a chair (PTHEA)

각 실험대상자는 골반이 테이블 가장자리에 있는 상태로 테이블 위 에 몸통을 올리고 엎드렸다. 운동 시작단계에서는 수준기(surface lev$\mathrm{el}$ 를 사용하여 실험대상자의 키에 따라 테이블의 높이를 조절하여, 엎드렸을 때 허리뼈를 중립 자세가 될 수 있게 하였다. 압력 바이오피 드백 도구는 중앙에 있는 실험대상자의 복부 아래에 위치했고 압력 은 $70 \mathrm{mmHg}$ 로 설정했다. 실험대상자는 지지하는 쪽 다리는 의자 위 에 무릎을 굽혀 올려놓고 체중지지가 가능하게 하였다. 엉덩관절 폄 이 수행되기 전에, 압력 바이오피드백 도구의 압력을 $70 \mathrm{mmHg}$ 에 맞 춰놓고, $60 \mathrm{mmHg}$ 까지 압력을 줄일 정도로 복부 당기기를 실시했다. 그 후에 엉덩관절 폄 각도가 타겟바에 도달할 때까지 우세측 다리를 천천히 들어 올리도록 하였다. 엉덩관절이 폄이 $10^{\circ}$ 에서 타겟바 도달 이 이뤄지면, 해당 자세를 5 초 동안 유지한 다음, 천천히 시작 위치로 돌아왔다(Figure 1A). 
2) PTHEA with the ipsilateral knee flexion (PTHEAF)

초기 실험자세는 PTHEA를 수행할 때와 동일하게 진행하였다. 실험 대상자는 지지하는 쪽 다리는 의자 위에 무릎을 굽혀 올려놓고, 엉덩 관절 폄이 수행되기 전에, 압력 바이오피드백 도구의 압력을 70 $\mathrm{mmHg}$ 에 맞춰놓고, $60 \mathrm{mmHg}$ 까지 압력을 줄일 정도로 복부 당기기 를 실시했다. 그 후에 측정하는 쪽의 무릎관절에서는 굽힘 $90^{\circ}$ 를 수 행한 채, 엉덩관절 폄 각도가 타겟바에 도달할 때까지 우세측 다리를 천천히 들어 올리도록 하였다. 무릎관절 굽힘 $90^{\circ}$ 와 엉덩관절 폄 $10^{\circ}$ 에서 타겟바 도달이 이뤼지면, 해당 자세를 5 초 동안 유지한 다음, 천 천히 시작 위치로 돌아왔다(Figure 1B).

\section{3) PTHEAF with hip 30 abduction (PTHEAFA)}

초기 실험자세는 PTHEAF를수행할 때와동일하게 진행하였다. 실험대 상자는지지하는 쪽다리는 의자 위에 무릎을 굽혀 올려놓고, 엉덩관절
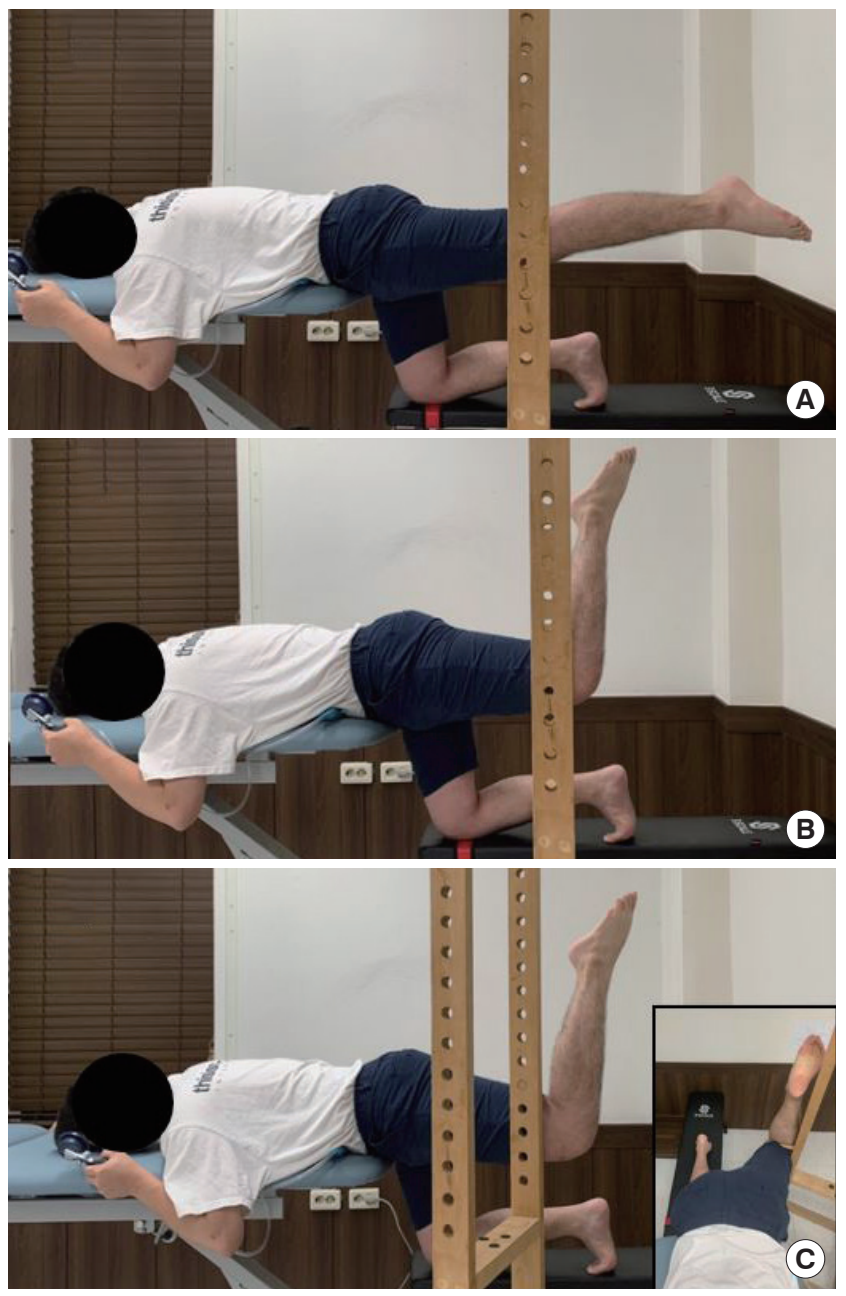

Figure 3. A: PTHEA (Prone table hip extension with the abdominal drawing-in maneuver on a chair), B: PTHEAF (Prone table hip extension with the abdominal drawing-in maneuver with the ipsilateral knee flexion on a chair, C: PTHEAFA (Prone table hip extension with the abdominal drawing-in maneuver with the ipsilateral knee flexion with hip 30 abduction on a chair).
폄이 수행되기 전에, 압력 바이오피드백 도구의 압력을 $70 \mathrm{~mm} \mathrm{Hg}$ 에 맞 춰놓고, $60 \mathrm{mmHg}$ 까지 압력을 줄일 정도로 복부 당기기를 실시했다. 그 후에, 측정하는 쪽의 무릎관절에서는 굽힘 $90^{\circ}$ 그리고 엉덩관절에서는 벌림 $30^{\circ}$ 를 수행한 채, 엉덩관절 폄 각도가 타겟바에 도달할 때까지 우세측다리를 천천히 들어 올리도록 하였다. 무릎관절 굽힘 $90^{\circ}$ 와 엉덩 관절 벌림 $30^{\circ}$, 그리고 폄이 $10^{\circ}$ 에서 타겟바 도달이 이뤼지면, 해당 자세 를 5 초 동안 유지한 다음, 천천히 시작 위치로 돌아왔다(Figure $1 \mathrm{C}$ ).

\section{5. 자료 분석}

본 연구의 모든 데이터는 IBM SPSS statistics 18.0 (SPSS Inc., Chicago, IL)을 사용하여 분석하였다. 측정 데이터의 정규성을 평가하기 위해 Kolmogorov-Smirnov 검정을 사용했다. 각각의 운동 동안에 근활성 도, 골반 움직임 그리고 근 수축 개시순서에 대한 비교를 하기 위해서 단순 반복측정분산분석을 사용하였고, 조건 간에 차이를 확인하기 위해 본페로니 post hoc 검사를 진행하였다(PTHEA vs. PTHEAF vs. PTHEAFA) $\mathrm{a}=\mathrm{a} /$ 종속 변수의 수(즉, $0.05 / 3=0.017$ ). 유의 수준은 $a=$ 0.01 로 설정했다.

\section{결 과}

\section{1. 큰볼기근과 뒤넙다리근의 근활성도}

세 가지 다른 PTHE 운동 동안에 근활성도에는 통계학적으로 유의 한 차이를 확인할 수 있었다( $\mathrm{p}<0.01$ (Table 1). PTHEAFA 운동 동안에 큰볼기근의 근활성도는 PTHEA과 PTHEAF 운동보다 통계학적으로 유의한 증가를 확인할 수 있었다. PTHEAF 운동 동안에 큰볼기근의 근활성도는 PTHEA 운동보다 통계학적으로 유의한 증가를 확인할 수 있었다 $(\mathrm{p}<0.01)$ (Table 1). PTHEAFA 운동 동안에 뒤넙다리근의 근 활성도는 PTHEA과 PTHEAF 운동보다 통계학적으로 유의한 감소 를 확인할 수 있었다. PTHEAF 운동 동안에 뒤넙다리근의 근활성도 는 PTHEA 운동보다 통계학적으로 유의한 감소를 확인할 수 있었다 $(\mathrm{p}<0.01)($ Table 1$)$.

Table 1. EMG amplitudes of the various muscles

\begin{tabular}{lccccc}
\hline \multirow{2}{*}{ Muscles } & \multicolumn{3}{c}{ Mean \pm SD $(\%$ MVIC $)$} & \multirow{2}{*}{ Fvalue } & p value \\
\cline { 2 - 4 } & PTHEA & PTHEAF & PTHEAFA & & \\
\hline GM & $25.01 \pm 13.74$ & $45.24 \pm 16.22^{*}$ & $57.12 \pm 17.24^{*}$ & 17.41 & $<0.01^{*}$ \\
HAM & $59.38 \pm 20.01$ & $31.35 \pm 11.72^{*}$ & $25.15 \pm 13.40^{*}$ & 14.52 & $<0.01^{*}$ \\
\hline
\end{tabular}

PTHEA: Prone table hip extension with the abdominal drawing-in maneuver on a chair, PTHEAF: Prone table hip extension with the abdominal drawing-in maneuver with the ipsilateral knee flexion on a chair, PTHEAFA: Prone table hip extension with the abdominal drawing-in maneuver with the ipsilateral knee flexion with hip 30 abduction on a chair, GM (dominant): Gluteus maximus on dominant side, HAM (dominant): Hamstring on dominant side, SD: Standard deviation.

*Significant difference between conditions ( $\left.P_{a d j}<0.017\right)$. 


\section{2. 허리골반 각도}

세 가지 다른 PTHE 운동 동안에 허리골반 부위의 돌림과 앞기울임 각도에서는 통계학적으로 유의한 차이를 확인할 수 없었다 $(\mathrm{p}>0.01)$ (Table 2).

\section{3. 큰볼기근과 뒤넙다리근의 근 수축 개시시간}

세 가지 다른 PTHE 운동 동안에 근활성도에는 통계학적으로 유의 한 차이를 확인할 수 있었다( $<<0.01$ (Table 3). PTHEAFA 운동 동안 에 큰볼기근의 근 수축 개시시간은 PTHEA과 PTHEAF 운동보다 통 계학적으로 유의하게 빨라짐을 확인할 수 있었다. PTHEAF 운동 동 안에 큰볼기근의 근 수축 개시시간은 PTHEA 운동보다 통계학적으 로 유의하게 빨라짐을 확인할 수 있었다 $(\mathrm{p}<0.01)$ (Table 3). PTHEAFA 운동 동안에 뒤넙다리근의 근 수축 개시시간은 PTHEA과 PTHEAF 운동보다 통계학적으로 유의하게 느려짐을 확인할 수 있었다 $(\mathrm{p}<0.01)$ (Table 3). PTHEAF 운동 동안에 뒤넙다리근의 근 수축 개시 시간은 PTHE운동과 통계학적으로 유의한 차이를 확인할 수 없었다 $(\mathrm{p}>0.01)$ (Table 3$)$.

\section{고 찰}

$\mathrm{PHE}$ 운동은 일반적으로 재활운동으로써 큰볼기근의 강화운동으로 사용되어 왔다.16,17 본 연구에서는 PTHEA, PTHEAF 그리고 PTHEA$\mathrm{FA}$ 의 세 가지 다른 PTHE 운동을 수행하는 동안 큰볼기근과 뒤넙다 리근의 근활성도, 허리골반부위의 보상작용 그리고 해당근육들의 수축 개시시간에 대해서 비교하는 연구이다.

PTHEAFA 운동을 수행하는 동안 PTHEA 그리고 PTHEAF 운동 을 수행할 때보다 큰볼기근 활성도의 유의한 증가와 뒤넙다리근 활 성도의 유의한 감소를 확인할 수 있었다. 또한 PTHEAFA 운동을 수 행하는 동안 PTHEA 그리고 PTHEAF 운동을 수행할 때보다 큰볼기 근 수축 개시시간이 유의하게 빨라짐을 확인할 수 있었다. 이전 연구 에 따르면 복부당기기 없이 PHE 운동을 수행하는 동안에 허리골반 부위에 다양한 보상작용 발생을 확인할 수 있었다.16,17 따라서 $\mathrm{PHE}$ 운 동을 수행하는 동안 복부당기기를 수행하면, 허리뼈의 돌림, 폄 각도

Table 2. Lumbopelvic kinematics during three different exercises

\begin{tabular}{lccccc}
\hline \multirow{2}{*}{ kinematics } & \multicolumn{3}{c}{ Mean \pm SD $\left({ }^{\circ}\right)$} & \multirow{2}{*}{ Fvalue } & p value \\
\cline { 2 - 4 } & PTHEA & PTHEAF & PTHEAFA & & \\
\hline Anterior tilting & $6.2 \pm 1.4$ & $6.8 \pm 0.9$ & $5.5 \pm 1.1$ & 3.64 & $>0.01$ \\
Rotation & $3.5 \pm 0.5$ & $4.4 \pm 0.7$ & $4.6 \pm 0.9$ & 2.79 & $>0.01$ \\
\hline
\end{tabular}

PTHEA: Prone table hip extension with the abdominal drawing-in maneuver on a chair, PTHEAF: Prone table hip extension with the abdominal drawing-in maneuver with the ipsilateral knee flexion on a chair, PTHEAFA: Prone table hip extension with the abdominal drawing-in maneuver with the ipsilateral knee flexion with hip 30 abduction on a chair, SD: Standard deviation.
가 감소하고, 골반에서 앞기울임, 돌림 각도가 감소했다. ${ }^{17}$ 본 연구에 서는 PTHEA, PTHEAF 그리고 PTHEAFA 모든 운동조건에서 복부 당기기를 수행했기 때문에 조건 간 보상작용 각도에 통계학적으로 유의한차이를 확인할수 없었다.

본 연구에서 PTHEA, PTHEAF 그리고 PTHEAFA의 세 가지 다른 PTHE 운동을 수행하는 동안 이러한 연구결과가 나온 이유가 몇 가 지 존재한다. 첫번째, 생체역학적 요소로 설명될 수 있다. PTHEAFA 운동을 수행하는 동안 PTHEA 그리고 PTHEAF 운동을 수행할 때보 다 큰볼기근의 유의한 증가를 보이는 이유는 바로 PTHEAFA 운동을 수행하면서 무릎관절에서는 $90^{\circ}$ 굽힘과, 엉덩관절에서는 $30^{\circ}$ 벌림을 수행했기 때문이다. 이와 같은 각 관절에서의 특정한 각도의 형성은 엉덩관절에서 큰볼기근이 선택적으로 근활성도를 더욱 증가시킬 수 있게 해준다. 무릎관절에서 $90^{\circ}$ 굽힘을 한 채 PTHE 운동을 수행할 경우, 엉덩관절 폄을 수행하기 위해 일반적으로 협동근으로 작용하 는 뒤넙다리근이 능동적 불충분을 발생시키기 때문에, 엉덩관절 폄 에 충분히 기여하지 못한다.317 그만큼 보완된 PTHE 운동 동안에 엉 덩관절 폄을 타겟바까지 수행하기 위해서 큰볼기근이 작용근으로써 기여가 더 요구되는 상태라고 볼 수 있다. 본 연구결과 중에서도 PTHEAF 운동을 수행할 때, PTHEA 운동을 수행할 때보다 큰볼기근 근활성도의 유의한 증가를 보인 현상은 같은 이유에서 설명될 수 있 을 것이다.

엉덩관절 $30^{\circ}$ 벌림의 경우, 큰볼기근의 근육섬유가 향하는 방향으 로 설명될 수 있다. 큰볼기근의 근육섬유는 엉치뼈(sacrum)로부터 넙 다리뼈 큰돌기(femur greater trochanter)를 향하기 때문에 바깥쪽 그 리고 아래쪽으로 대략 $30^{\circ}$ 의 각도를 형성하고 있다. 따라서 넙다리 벌 림 각도를 큰볼기근의 근육섬유 각도 $30^{\circ}$ 와 일치시킬 때, 근활성도는 더욱 증가될 수 있다. 선행연구에 따르면, 일반적인 PHE 운동(conventional PHE)을 수행할 때, 엉덩관절 벌림 각도를 $0^{\circ}, 15^{\circ}, 30^{\circ}$ 에서 수행 한 연구결과에서는 엉덩관절 벌림 $30^{\circ}$ 각도에서 큰볼기근의 근활성 도가 가장 증가된 것을 확인할 수 있었다. ${ }^{21}$ 선행연구에서 수행된 일 반적인 PHE 운동과 달리 보완된 PTHE 운동은 양쪽 다리를 모두 내

Table 3. The onset time between GM and HAM

\begin{tabular}{lccccc}
\hline \multirow{2}{*}{ Onset time } & \multicolumn{3}{c}{ Mean \pm SD $(\mathrm{ms})$} & \multirow{2}{*}{ Fvalue } & p value \\
\cline { 2 - 4 } & PTHEA & PTHEAF & PTHEAFA & & \\
\hline GM & $0.86 \pm 0.18$ & $0.65 \pm 0.23^{*}$ & $0.45 \pm 0.19^{*}$ & 15.94 & $<0.01^{*}$ \\
HAM & $0.69 \pm 0.25$ & $0.69 \pm 0.19$ & $0.78 \pm 0.18^{*}$ & 12.76 & $<0.01^{*}$ \\
\hline
\end{tabular}

PTHEA: Prone table hip extension with the abdominal drawing-in maneuver on a chair, PTHEAF: Prone table hip extension with the abdominal drawing-in maneuver with the ipsilateral knee flexion on a chair, PTHEAFA: Prone table hip extension with the abdominal drawing-in maneuver with the ipsilateral knee flexion with hip 30 abduction on a chair, GM (dominant): Gluteus maximus on dominant side, HAM (dominant): Hamstring on dominant side, Mean \pm standard deviation (ms).

*Significant difference between conditions ( $\left.\mathrm{Padj}_{\mathrm{j}}<0.017\right)$. 
려놓고 시작할 뿐만 아니라, 테이블에 몸통만 지지한 채 수행하는 자 세 때문에 직접적으로 비교하기에는 한계가 존재한다. 하지만 엉덩관 절의 관점에서는 동일하게 폄 동작이 발생하기 때문에 선행연구에서 와같은 연구결과를 확인할 수 있었다.

두번째로 복부당기기를 통한 안정화근육활성화(stabilizing muscle activation)로 설명될 수 있다. 본 연구결과에서는 PTHEA, PTHEAF 그 리고 PTHEAFA의 세가지 다른 PTHE 운동을 수행하면서 발생될 수 있는 허리골반 부위에서의 돌림, 앞기울임에 대한 보상작용을 비교 하였다. 하지만 각 조건 사이에서 통계학적으로 유의한 차이를 확인 할 수 없었다. 세 가지 모든 PTHE 운동을 수행하면서 압력 바이오피 드백 도구를 사용하여 복부당기기를 선행했기 때문에, 발생할 수 있 는 보상작용을 최소화시킬 수 있었고, 모든 조건에서 수행한 만큼 통 계학적으로 유의한 차이는 발생하지 않았다. 선행연구결과를 보면, 엉덩허리근 단축(shortness)이 있는 대상자에서 PHE 운동을 수행했 을 때, 허리골반 부위에서 보상작용이 나타났고, 엉덩허리근 신장을 수행한 후 복부당기기를 수행하며 PHE 운동을 했을 때, 보상작용이 크게 감소함을 확인할 수 있었다. ${ }^{22}$ 이렇듯, 엉덩관절 폄 운동을 수행 하기 위해서 정상적인 엉덩허리근의 길이를 확보하는 것은 허리골반 부위에서 발생하는 보상작용을 감소시키는데 필수적이라고 할 수 있다.22 게다가 테이블에 엎드려 엉덩관절 폄이 일어나면서, 복부당기 기를 통해 몸통의 안정화근육을 활성화시켰기 때문에 허리골반 안 정화에 도움을 준 것으로 생각된다. 하지만 이 연구에서는 연구대상 자가 엉덩허리근 단축이 없이 건강한 상태이기 때문에, PTHE 운동 을 수행하면서 복부당기기를 선행함으로써 발생할 수 있는 보상작 용을 최소화시킬 수 있었다.

세번째로 PTHEAFA 운동 시 엉덩관절과 무릎관절의 자세로 큰볼 기근 수축 개시시간 단축을 설명할 수 있다. PTHEAFA을 수행하면 서, 엉덩관절 $30^{\circ}$ 벌림과 무릎관절 $90^{\circ}$ 굽힘을 수행함으로써 큰볼기 근의 유의한 증가와 뒤넙다리근의 유의한 감소를 확인했다. 이와 같 은 엉덩관절과 무릎관절의 자세적 변화를 통해 큰볼기근과 뒤넙다 리근 사이에서 협동근으로써의 근육 균형(muscle balance)의 향상이 일어났기 때문이다. $4,5,17$ 무릎관절 $90^{\circ}$ 굽힘을 통해 뒤넙다리근의 능 동적 불충분을 발생시키며, 엉덩관절 폄에 기여할 수 있는 정도는 최 소화되서 근 수축 개시시간에 지연을 야기시켰고, 엉덩관절 $30^{\circ}$ 벌림 을 통해 큰볼기근이 엉덩관절 폄에 작용근으로써 최대한 기여해서 근 수축 개시시간을 단축시키는데 영향을 미쳤다고 본다. 선행연구 에서도 일반적인 $\mathrm{PHE}$ 운동을 수행하면서 엉덩관절 벌림 $30^{\circ}$ 를 수행 했을 때 벌림 $0^{\circ}$ 와 $15^{\circ}$ 에 비해서 근 수축 개시시간에 유의한 단축을 확인할 수 있었다. ${ }^{21}$ 또한 PHE 운동을 수행하면서, 근 수축 개시시간 에 있어서 큰볼기근에 지연과 뒤넙다리근에 단축이 발생될 경우, 엉 덩관절 폄을 하는 동안 넙다리뼈의 중심축(axis)이 앞으로 많이 이동
될 수 있다.5,15 단관절 근육인 큰볼기근이 엉덩관절 폄 동안에 먼저 활 성화가 되면, 넙다리뼈의 중심축이 앞으로 이동되는 넙다리뼈 앞쪽 활주 증후군(femoral anterior gliding syndrome)이 발생하지 않는다. 반 대로, 다관절 근육인 뒤넙다리근이 큰볼기근 수축보다 더 빨리 우세 화되면서 넙다리뼈의 중심축이 앞으로 이동되는 현상을 야기시킬 수 있다. ${ }^{5,15}$

본 연구에는 몇가지 제한점이 존재한다. 첫째, 우리의 연구 결과는 모든 실험대상자가 건강한 남성이었기 때문에 여성에게 일반화될 수 없다. PTHEA, PTHEAF 그리고 PTHEAFA의 세 가지 다른 PTHE 운 동을 수행하는 동안 성별에 따른 추가 연구가 필요하다. 둘째, 세 가 지 다른 PTHE 운동을 수행하는 동안 넙다리뼈의 이동은 측정되지 않았다. 각 컨디션에 따른 운동 수행 중, 넙다리뼈 이동에 대한 비교 연구가 필요하다. 셋째, 운동자세로 인해 복부에는 근활성도를 측정 하지 않았다. 복부 당기기를 사용하여 복부 근육의 활성화를 향상시 켰다.

따라서 PTHEA, PTHEAF 그리고 PTHEAFA 의 세 가지 다른 PTHE 운동을 수행하는 동안 근활성도에 있어서 큰볼기근의 촉진과 뒤넙 다리근의 억제를 통해 선택적인 큰볼기근 강화운동이 가능할 수 있 고, 큰볼기근의 수축 개시시간 단축을 통해 엉덩관절에서 더 정확하 고, 효율적인 운동이 될 수 있었다. 따라서 PTHEAFA 운동이 임상적 으로 추천될 수 있다.

\section{ACKNOWLEDGEMENTS}

본 연구는 산업통상자원부와 한국산업기술진흥원의 “지역산업거점 기관지원사업"(과제번호: R0006231)으로 수행된 연구임.

\section{REFERENCES}

1. Jeon IC, Hwang UJ, Jung SH et al. Comparison of gluteus maximus and hamstring electromyographic activity and lumbopelvic motion during three different prone hip extension exercises in healthy volunteers. Phys Ther Sport. 2016;22:35-40.

2. Neumann DA. Kinesiology of the musculoskeletal system: foundation for rehabilitation. 3rd ed. Missouri, Mosby, 2017:488-509.

3. Kendall FP, McCreary EK, Provance PG. Muscles testing and function. 5th ed. Baltimore, Williams \& Wilkins, 2005:433-46.

4. Kisner C, Colby LA. Therapeutic Exercise: foundations and techniques. Philadelphia, FA Davis Company, 2012:764-6.

5. Sahrmann SA. Diagnosis and treatment of movement impairment syndromes. 1st ed. Missouri, Mosby, 2002:220-49.

6. Lieberman DE, Raichlen DA, Pontzer H et al. The human gluteus maximus and its role in running. J Exp Biol. 2006;209(11):2143-55.

7. Hungerford B, Gilleard W, Hodges P. Evidence of altered lumbopelvic muscle recruitment in the presence of sacroiliac joint pain. Spine. 2003; 
28(14):1593-600.

8. Hossain M, Nokes LDM. A model of dynamic sacro-iliac joint instability from malrecruitment of gluteus maximus and biceps femoris muscles resulting in low back pain. Med Hypotheses. 2005;65(2):278-81.

9. Kim MK, Cho YH Park JW et al. The effects of the contraction degree of hip joint adductor on abdominal muscle activity during bilateral lower extremity raising. J Kor Phys Ther. 2016;28(3):217-20.

10. Chance-Larsen K, Littlewood C, Garth A. Prone hip extension with lower abdominal hollowing improves the relative timing of gluteus maximus activation in relation to biceps femoris. Man Ther. 2010;15 (1):61-5

11. Lewis CL, Sahrmann SA. Muscle activation and movement patterns during prone hip extension exercise in women. J Athl Train. 2009;44 (3):238-48.

12. Wilson J, Ferris E, Heckler A et al. A structure review of the role of gluteus maximus in rehabilitation. NZ J Physiother. 2005;33(3):95-100.

13. Distefano LJ, Blackburn JT, Marshall SW et al. Gluteal muscle activation during common therapeutic exercises. J Orthop Sports Phys Thera. 2009;39(7):532-40.

14. Cappozzo A, Felici F, Figura F et al. Lumbar spine loading during halfsquat exercises. Med Sci Sports Exer. 1985;17(5):613-20.

15. Comerford M, Mottram S. Kinetic control: the management of uncontrolled movement. Churchill Livingstone, Australia Elsevier, 2012;220-4.
16. Oh JS, Cynn HS, Won JH et al. Effects of performing an abdominal drawing-in maneuver during prone hip extension exercises on hip and back extensor muscle activity and amount of anterior pelvic tilt. J Orthop Sports Phys Ther. 2007;37(6):320-4.

17. Jeon IC, Kwon OY, Weon JH et al. Comparison of hip-and back-muscle activity and pelvic compensation in healthy subjects during 3 different prone table hip-extension exercises. J Sport Rehabil. 2017;26(4):216-22.

18. Rainoldi A, Melchiorri G, Caruso I. A method for positioning electrodes during surface EMG recordings in lower limb muscles. J Neurosci Methods. 2004;134(1):37-43.

19. Kerrigan DC, Ehrenthal SR. A maladaptive gait abnormality in patients with lumbar spinal stenosis. J Back Musculoskelet Rehabil.1996;7 (1):53-7.

20. Lim HW. The effect of motor imagery on onset time of leg muscle and ankle injury score of patients with functional ankle instability. J Kor Phys Ther. 2012;24(1):7-14.

21. Kang SY, Jeon HS, Kwon OY et al. Activation of the gluteus maximus and hamstring muscles during prone hip extension with knee flexion in three hip abduction positions. Man Ther. 2013;18(4):303-7.

22. Jeon IC, Jang JH. Comparison of prone hip extension exercise and prone hip extension exercise after iliopsoas stretching on lumbopelvic control and gluteus maximus activity in subjects with short iliopsoas. JMST. 2017;1(1):19-25. 